\title{
Enzyme assays on GPx and SOD in alloxan-induced diabetic mice given yellow velvet leaf (Limnocharis flava) ethanol extracts
}

\author{
Yithro Serang*, Metrikana Novembrina, Henry Setiawan Haryanto, \\ Siti Erni Saputri \\ Nusaputera College of Pharmacy \\ Jl.Medoho 3, No 2, Semarang, Central Java, Indonesia
}

Reviewed: 20-05-2020

Accepted: 12-10-2020

\begin{abstract}
In a pathological condition such as diabetes, the increase of oxidative stress may decrease endogenous antioxidant activities, so the body cannot detoxify free radicals and prevent cell damage. The yellow velvet leaf is one of the natural antioxidant sources. This research investigates antihyperglycemic activities of ethanol extracts from yellow velvet leaves and SOD and GPx activities, the antioxidant enzymes. This experimental laboratory research used a posttest only group design. This research subjects were 25 alloxan-induced white male rats of Wistar strains conditioned as the type 2 Diabetes Mellitus (DM). The rats were clustered into five groups: the group I was the no-treatment control group, the group II was the positive control group given glibenclamide $0.45 \mathrm{mg} / \mathrm{kg} \mathrm{BW}$ (rat's body weight) as the treatment, and group III, IV, and V were the experimental groups treated with yellow velvet leaf ethanol extracts with the doses of $32.5 \mathrm{mg} / \mathrm{kg} \mathrm{BW}, 65 \mathrm{mg} / \mathrm{kg} \mathrm{BW}$ and $130 \mathrm{mg} / \mathrm{kg}$ BW respectively. The activity tests of SOD and GPx, furthermore, were conducted. The results revealed that the dose of $130 \mathrm{mg}$ was the most effective in increasing SOD and GPx activities. The increase of SOD and GPx levels also influenced the blood glucose level, which decreased significantly on 130mg. When the blood sugar level decreases, the stress oxidative itself can be reduced, increasing the endogenous antioxidant activities. It was concluded that yellow velvet leaf ethanol extracts (Limnocharis flava) on the dose of $130 \mathrm{mg} / \mathrm{kg}$ BW has a significant influence on SOD and GPx activities in alloxan-induced diabetic RA, and not significantly different from glibenclamide.
\end{abstract}

Keywords: yellow velvet leaf, superoxide dismutase, glutathione peroxidase, diabetic

\footnotetext{
*Corresponding author:

Yithro Serang

Nusaputera College of Pharmacy

Jl.Medoho 3, No 2, Semarang, Central Java, Indonesia

Email: ithoserang@gmail.com
} 


\section{INTRODUCTION}

Diabetes is a degenerative disease, and its occurrence tends to increase in Indonesia. International Diabetes Federation (2013) estimated that from 154 million people in Indonesia with ages ranging from 20 to 79 years old, there were 3.6 million men and 4.9 million women who suffered diabetes (Rustanti, 2014).

Diabetes Miletus (DM) can increase the production of free radicals through glucose autoxidation and protein glycation. Furthermore, the oxidative degradation from free radicals contributes to lipid peroxidation; the increase of this reactive oxygen level is caused by the imperfect antioxidant, immune system, or the body's inability to repair the oxidative damage. What happens in DM patients is that the hyperglycemia condition induces oxidative stress, and this kind of stress can damage DM sells (Monroy and Mejia, 2013).

Oxidative stress increase can be checked by antioxidants that function as the stabilizer of free radicals. Antioxidants, moreover, provide the lack of free radical electrons and inhibit the chain reactions that may occur due to the forming of free radicals. Based on their sources, antioxidants are divided into two, namely endogenous antioxidants and exogenous antioxidants. The endogenous antioxidants are enzymes inside the body that have characteristics as an antioxidant such as Superoxide Dismutase (SOD), catalase (Cat), and glutathione peroxidase (GPx). In contrast, the exogenous antioxidants are the ones found outside the body or within the food. The glutathione peroxidase (GPx) enzymes are the endogenous enzymes that break radical $\mathrm{H}_{2} \mathrm{O}_{2}$ to be $\mathrm{H}_{2} \mathrm{O}$ with the glutathione substrates (GSH). Moreover, improving antioxidants' ability to inhibit the escalation of oxidative stress can be conducted by increasing exogenous antioxidants. Therefore, non-nutrient compounds in food like phenols, polyphenols, dan flavonoids can function as antioxidants (Zakaria, et al., 2011). According to the research conducted by (Bajaj and Khan, 2012), it was said that the exogenous antioxidants which were obtained from vegetables and fruits compensated for the lower plasma antioxidant levels, which was often observed in type $2 \mathrm{DM}$.

Yellow velvet leaves or daun genjer (Limnocharisflava) are aquatic plants that can be a potential alternative for the natural antioxidant. The yellow velvet leaves are the native plants found in both tropical areas and subtropical areas of America, and these plants are usually consumed by the people there. In Indonesia, the processing of these plants is done by steaming, boiling, or stir-frying (Nurjanah et al.,2014).

The research result of (Pitchaon et al., 2008) showed that yellow velvet leaves in Thailand areas contained total phenolic as many as $5.4 \mathrm{mg}$ GAE/g in dry weight and total flavonoid as many as 3.7 $\mathrm{mg} \mathrm{RE} / \mathrm{g}$ in dry weight. It indicated that yellow velvet leaf had a potency as an antioxidant source that could counter free radicals and helped lower blood sugar levels by improving insulin's sensibility increase of its quantity. The purpose of this research is to comprehend the influence of ethanol extract from yellow velvet leaves (Limnocharis flava) on the enzymatic activities of both GPx and SOD in alloxan-induced diabetic rats.

\section{MATERIALS AND METHOD \\ Materials}

Chemical agents: Alloxan (Sigma), SOD and GPx reagent kits (Biovision),

\section{Animal}

The experiments were performed on male Wistar rats (150-180 g) obtained from Pharmacology Laboratory, Nusaputera College of Pharmacy. All aspects of animal care complied with the ethical guidelines and technical requirements approved by the Institutional Animal Ethics Committee of Faculty of Medicine, Universitas Sultan Agung with approval number 298/IX/2020/Bioethics Commission. 
Animals were housed individually in glass-bottomed metabolic cages in an environmentally controlled animal facility $\left(22 \pm 1{ }^{\circ} \mathrm{C}\right.$, humidity $60 \pm 5 \%, 12 \mathrm{~h}$ light : $12 \mathrm{~h}$ dark cycle) with free access to a standard commercial diet and water ad libitum. The weight gain, food and water intake, and urine output were determined daily in the morning.

\section{Methods \\ Extraction}

The yellow velvet leaves were obtained from Ngemplak Village, Mranggen District, Demak Regency. The determination testing was carried out in the laboratory of STIFAR "Yayasan Pharmasi", Semarang. The leaves were cleaned, drained, chopped, and weighed out $1500 \mathrm{~g}$. It was then dried for 3-4 days within room temperature and put into the maceration vessel where ethanol $70 \%$ was added. The leaves were macerated for $3 \times 24$ hours, and stirring was done during maceration for 3 hours each day. After that, the leaves were filtered until the results of maceration were yielded twice. Furthermore, the filtrate was mixed and evaporated in the evaporator at $\pm 40{ }^{\circ} \mathrm{C}$ to get the condensed extract.

\section{Induction and treatment of diabetes}

Diabetes was induced by a single injection of alloxan $60 \mathrm{mg} / \mathrm{kg} \mathrm{b}$.w. to rat fasting for at least 16 $\mathrm{h}$ through the tail vein in freshly prepared $10 \mathrm{mmol} / \mathrm{l}$ sodium citrate, $\mathrm{pH} 4.5$. Blood glucose levels were measured daily 3 days prior and 7 days after alloxan administration. The development of diabetes mellitus was proven by sustained hyperglycemia and glycosuria (diabetic rats had glycemia> 16 $\mathrm{mmol} / \mathrm{l})$.

\section{Experimental design}

This experimental laboratory research used a posttest only group design. This research's subject was 25 alloxan-induced white male rats of Wistar strain conditioned as the type 2 diabetes mellitus (DM). The rats were clustered into five groups: the group I was the no-treatment control group, the group II was the positive control group given glibenclamide $0.45 \mathrm{mg} / \mathrm{kg} \mathrm{BW}$ (bodyweight) as the treatment, and group III, IV, and V were the experimental groups given yellow velvet leaf ethanol extracts doses $32.5 \mathrm{mg} / \mathrm{kg} \mathrm{BW}, 65 \mathrm{mg} / \mathrm{kg} \mathrm{BW}$ and $130 \mathrm{mg} / \mathrm{kg} \mathrm{BW}$ respectively.

\section{The treatment given to the rat's liver}

The livers were cleaned with physiological saline $(\mathrm{NaCl} 0.9 \%)$ and were minced in a cold condition. The homogenates yielded from the previous process was then centrifuged as fast as 4000 RPM for 10 minutes, so the clear supernatants were obtained. These supernatants were used to measure the enzymes.

\section{GPx activity test}

The $200 \mu \mathrm{l}$ buffer phosphate $0.1 \mathrm{M} \mathrm{pH} 7.0$ and $200 \mu \mathrm{l}$ reduced glutathione (GSH) $10 \mathrm{mM}$ were added to clear supernatants $20 \mu \mathrm{l}$ before the supernatants were incubated for 10 minutes at a temperature of $37^{\circ} \mathrm{C}$. The next process was the addition of $200 \mu 1 \mathrm{NADPH} 1.5 \mathrm{mM}$ before it was incubated again for 3 minutes at a temperature of $37^{\circ} \mathrm{C}$. After that, $200 \mu \mathrm{l} H 2 O 21.5 \mathrm{Mm}$ were added, and absorbance was measured with a spectrophotometer at $340 \mathrm{~nm}$ wavelength.

\section{SOD activity test}

Protein standard solution was made by weighing 0.01g of BSA (Bovine Serum Albumin), which was then dissolved using $10 \mathrm{~mL}$ of $\mathrm{H}_{2} \mathrm{O}$, then producing a stock solution of BSA with $1000 \mathrm{ppm}$ concentration. This solution was diluted by dissolving $0.5 \mathrm{~mL}$ of the stock solution and adding $4.5 \mathrm{~mL}$ of $\mathrm{H}_{2} \mathrm{O}$, which eventually yielded $100 \mathrm{ppm}$ of BSA stock solution. After that, the measurement of protein standard was done by adding $0.1 \mathrm{~mL}$ of the standard solution and $5 \mathrm{~mL}$ of Bradford reagent. 
The solution was then vortexed, and the blue color would be seen and read at a wavelength of $595 \mathrm{~nm}$. The sample's measurement was done by adding $8 \mu$ l of supernatants taken from the sample to $80 \mu 1$ of Biorad reagent and $321 \mu \mathrm{l}$ of aqua dest, which was then vortexed and read at the wavelength $595 \mathrm{~nm}$. Besides, the samples that would be read were incubated at room temperature for 30 seconds.

\section{Data Analysis}

The collected quantitative data were the number of diabetic rats having activities of GPx and SOD in their liver. Data were analyzed using the Anova One Way test and the SPSS 21 software to compare each group using the LSD post hoc test.

\section{RESULT AND DISCUSSIONS}

\section{Effect of yellow velvet leaf ethanol eaxtract on blood glucose level}

The qualitative identification of ethanolic extract of yellow velvet leaves was done in the Nusaputera College of Pharmacy laboratory. Color test and thin layer Chromatography were used to identify the alkaloids, flavonoids, saponins, and tannins. The result showed that there were bioactive compounds or compounds having antioxidant activities. According to the phytochemical screening, the chemical compounds found were alkaloids, flavonoids, saponins, and tannins. The tested animals were induced intraperitoneally with alloxan as the diabetogenic agent to assess ethanol extracts of yellow velvet leaves' capability in decreasing the blood glucose level. Alloxan, and the products of its reduction, dialuric acid, show the redox cycle with the formation of superoxide radicals (Szkudelski, 2001). It may cause oxidative stress in $\beta$-cells, and such stress is also experienced by patients suffering from diabetes. The glucose level reaches $200 \mathrm{mg} / \mathrm{dL}$ was an indication of hyperglycemia. Furthermore, in the treatment group, the increase of the rat's glucose level was $>200 \mathrm{mg} / \mathrm{dL}$, and it showed that the induction of diabetogenic agents was successfully conducted. Hence, DM contracted rat.

After they were given treatments for 35 days, the rat's glucose level measurement showed that the $0.45 \mathrm{mg} / \mathrm{kg} \mathrm{BW}$ glibenclamide, as the positive control group, had the highest average value in lowering the blood glucose level. According to this fact, it means that the positive control group, the glibenclamide $0.45 \mathrm{mg} / \mathrm{kg} \mathrm{BW}$ (mice's body weight), had the highest activities in decreasing rat's blood glucose level, followed by the $130 \mathrm{mg} / \mathrm{kg}$ BW yellow velvet leaf ethanol extracts group, the $65 \mathrm{mg} / \mathrm{kg} \mathrm{BW}$ yellow velvet leaf ethanol extracts group, the $32.5 \mathrm{mg} / \mathrm{kg}$ BW yellow velvet leaf ethanol extracts group, and the $0.5 \% \mathrm{CMC}$ negative control group as the lowest one. Figure 1 shows that the $130 \mathrm{mg} / \mathrm{kg}$ BW yellow velvet leaf ethanol extracts group has the best activities in decreasing rats' blood glucose levels among the experimental groups even though it is not as good as the positive control group. The facts mentioned above have shown that the dosage influences anti-hyperglycemic activities; hence the higher the dose, the better the anti-hyperglycemic activities.

Glibenclamide has been known as an anti-diabetic drug that can decrease blood glucose level by stimulating $\beta$-cells of the pancreas to release insulin and increase insulin secretion due to glucose stimuli (Sidartawan, 2005). The statistical test proved that the average decrease in blood glucose level was normally distributed. Therefore, One Way Anova was applied, and the result was Asymp. Sig. $<0.05$, which means there was a significant difference in the decrease of blood glucose levels on average each group. The post hoc test was then applied to see the most effective influence among the given interventions or doses in decreasing the blood glucose level. In this way, it can be seen that ethanol extract of yellow velvet leaves can bring an impact in reducing the average blood glucose level of alloxan-induced rats since these extracts have chemical/bioactive compounds that can reduce the blood sugar level (Nurjanah et al., 2014). These bioactive compounds, such as alkaloids, flavonoids, tannins, and saponins, are antioxidants that play an essential role in diminishing diabetic-related complications and recovering insulin sensitivity. Therefore, insulin can bring glucose into the cells and lower its level in the bloodstream (Rajendiran et al., 2018). 


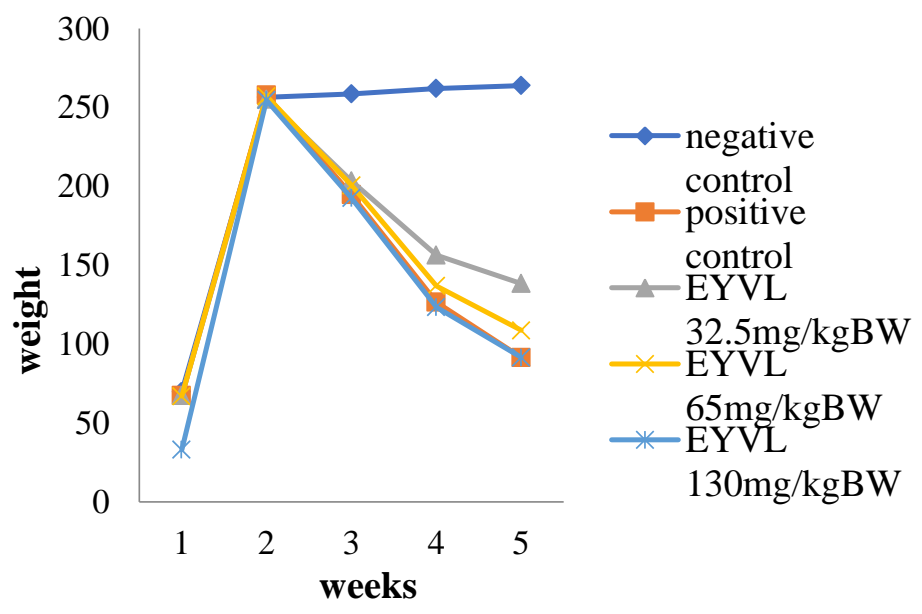

Figure 1. The decrease in blood glucose level of diabetic rats treated by yellow velvet leaf ethanol extract given in three varied doses compared to the negative and positive control. (EYVL: ethanol extract of yellow velvet leaf)

The post hoc test result between the control (+) and the $130 \mathrm{mg} / \mathrm{kg}$ BW yellow velvet leaf ethanol extract was 0.003 . Therefore, the yellow velvet leaf ethanol extract made a significant difference because $\mathrm{p}<0.05$, and it means that this extract can increase blood glucose level alloxaninduced rat.

\section{The effect of yellow velvet leaf extract on SOD and GPx activities}

The capability of yellow velvet leaf ethanol extract to increase antioxidant enzymes' activities can be evaluated by measuring the enzyme level of SOD and GPx within the rat's blood after they were given treatment for 35 days. Table 1 shows that the values of both SOD and GPx are high, which means that the tested rats were in normal condition; this table also describes that the normal control group contained the healthy rat. Moreover, the SOD value (\%) shows the number of superoxide anion that was successfully checked. The value of GPx indicates the number of enzymes needed to catalyze oxidation from $1 \mathrm{nmol}$ NADPH per minute within $1 \mathrm{mg}$ of protein.

Table1. The increasing of SOD and GPx activities on yellow velvet leaf ethanol extract in treated rat

\begin{tabular}{|c|c|c|c|}
\hline \multirow[t]{2}{*}{ Groups } & \multirow[t]{2}{*}{$\mathbf{n}$} & \multicolumn{2}{|c|}{ Activities of GPx and SOD in Average \pm SD } \\
\hline & & GPx (U/mg) & SOD (U/mg) \\
\hline Negative control & 5 & $19.80 \pm 2.42$ & $32.44 \pm 4.43$ \\
\hline Possitive control & 5 & $77.68 \pm 2.43^{\mathrm{b}}$ & $71.73 \pm 4.13^{\mathrm{b}}$ \\
\hline $\begin{array}{l}\text { EYVL } \\
32.5 \mathrm{mg} / \mathrm{kgBW}\end{array}$ & 5 & $41.28 \pm 2.52^{\mathrm{a}, \mathrm{b}}$ & $45.54 \pm 3.34^{\mathrm{a}}$ \\
\hline $\begin{array}{l}\text { EYVL } \\
65 \mathrm{mg} / \mathrm{kgBW}\end{array}$ & 5 & $62.25 \pm 2.70^{\mathrm{a}, \mathrm{b}}$ & $57.74 \pm 3.85^{\mathrm{a}}$ \\
\hline $\begin{array}{l}\text { EYVL } \\
130 \mathrm{mg} / \mathrm{kgBW}\end{array}$ & 5 & $72.45 \pm 2.36^{\mathrm{b}}$ & $69.94 \pm 5.10^{\mathrm{b}}$ \\
\hline
\end{tabular}


In addition, during the hyperglycemia condition, glucose metabolism will occur in alternative pathways, namely glucose autoxidation, glycation, and dicarbonyl development. All of these pathways, furthermore, will create hydroxyl radicals $(\mathrm{OH})$ and superoxide radicals $(\mathrm{O})$, and this excessive development cannot be neutralized by SOD and GPx (Xu et al., 2019).

In this research, alloxan was applied as the free radical agent that damages the rat's pancreas. Such hyperglycemia condition would cause a higher number of free radical development. There were actually decreases of SOD and GPx levels in the negative control group. However, based on the statistical analysis, the positive control group showed a significant increase in the SOD and GPx levels $(\mathrm{p}<0.05)$. Glibenclamide increased insulin secretion from the pancreas escalating blood glucose intake, so blood glucose level decreased. Also, glibenclamide caused the pancreas' homeostasis to work well so that the endogenous enzymes could neutralize free radicals (Kamlasi, 2015). The statistical test, One Way Anova, also presented that all experimental groups' SOD and GPx levels significantly differed from the negative control group. Therefore, it is evident that the given treatments were increasing the level of SOD and GPX.

Based on the statistical test results, all experimental groups were significantly different from both positive and negative control groups. This fact shows that statistically, ethanol extracts of yellow velvet leaves have not been as effective as glibenclamide in increasing SOD and GPx levels. However, the graphic describing the average leve of SOD and GPx shows that the $130 \mathrm{mg} / \mathrm{kg} \mathrm{BW}$ yellow velvet leaf ethanol extract, the highest dose, has shown a significant capability in decreasing SOD and GPx levels. Such efficacy is indeed closely connected with the significant decrease in blood glucose levels.

The compounds considered to have antioxidant activities are flavonoids, alkaloids, and tannins. Flavonoids are potential antioxidants because hydroxyl groups bond to aromatic carbon rings so that these compounds can capture free radicals occurring from lipid peroxidation. Flavonoids, furthermore, will transfer one hydrogen atom to stabilize radical lipid peroxide.

The ability of flavonoids, in addition, has already been a popular subject to research, and one of these compound's abilities is changing or reducing free radicals and becoming anti-free radicals (Weber et al., 2001). Rajendiran et al. (2018), in their review on the antioxidant role in diabetes, also suggested that the active constituents responsible for hypoglycemic activity may include: polysaccharides, sterol, triterpenoid, alkaloids, flavonoids, fat, coumarins, phenolics, and peptides. These bioactive compounds work as an antioxidant which stimulates the beta-cell to restore the function of pancreatic tissue.

The working mechanism of saponins in lowering the blood glucose level is by changing the intestine membrane structure to be more permeable to macromolecules. Therefore, the absorption of micromolecules like glucose can be inhibited (Fiana and Oktaria, 2016).

According to (Bunting et al., 2006), alkaloids can stimulate the hypothalamus to increase the secretion of Growth Hormone Releasing Hormone (GHRH), and the secretion of Growth Hormone $(\mathrm{GH})$ at hypophysis will increase. The high level of $\mathrm{GH}$ will eventually stimulate the liver to produce and release Insulin-like Growth Factor-1 (IGF-1). Such insulin affects hypoglycemia induction and decreases gluconeogenesis. Therefore, the level of blood glucose and the need for insulin are reduced.

The phytochemical results from yellow velvetleaf extracts have shown several secondary metabolites such as flavonoids, alkaloids, saponins, and these metabolites can function both as antihyperglycemia and as antioxidants (Fei et al., 2015).

\section{CONCLUSION}

The yellow velvet (Limnocharis flava) leaf ethanol extract on the dose of $130 \mathrm{mg} / \mathrm{kg} \mathrm{BW}$ has a significant influence on SOD and GPx activities in alloxan-induced diabetic rats by increasing its level in the body to counteract the effect of free radicals. 


\section{ACKNOWLEDGEMENT}

This research was internal research funded by Nusaputera College of Pharmacy. The number of the contract was 02/KP/LPPM/1/2020.

\section{REFERENCES}

Bajaj, S., \& Khan, A. (2012). Antioxidants and diabetes. Indian Jounal Endocrinol Metab, 16((Suppl 2)), S267-S271.

Bunting, K., Wang, J. K., \& Shannan, M. F. (2006). Control of Interleukin-2-gene Transcription: A Paradigm for Inducible, Tissue Specific Gene Expression,. Elsevier Academic Press, 74, 105145.

Fei, O. K., Ong, H.-C., Wong, F.-C., \& Chai, T.-T. (2015). HPLC profiling of phenolic acids and flavonoids and evaluation of anti-lipoxygenase and antioxidant activities of aquatic vegetable Limnocharis flava. Acta Poloniae Pharmaceutica, 75(2), 973-979.

Fiana, N., \& Oktaria, D. (2016). Pengaruh kandungan saponin dalam daging buah mahkota dewa (Phaleria macrocarpa) terhadap penurunan kadar glukosa darah. Jurnal Majority, 5(4), 128-132.

Kamlasi, J. E. . (2015). Efek antihiperglikemik, antioksidan dan proteksi pankreas ekstrak etanol biji jinten hitam (Nigella sativa L.) pada tikus yang diinduksi aloksan. Thesis,Universitas Setia Budi, Surakarta.

Monroy, M., \& Mejia, C. (2013). Oxidative stress in diabetes mellitus and the role of vitamins with antioxidant actions. Intech, (9), 209-231.

Nurjanah, Jacoeb, A. M., Roni Nugraha, M. P., \& Sejati, T. K. A. (2014). Perubahan komposisi kimia, aktivitas antioksidan, vitamin $\mathrm{C}$ dan mineral tanaman genjer (Limnocharis flava) akibat pengukusan. Jurnal Inovasi Dan Kewirausahaan, (3), 185-195.

Pitchaon, M., Pasuk, S., \& Ritthiruangdejc, P. (2008). Relathionship between antioxsidant properties and chemical composition of some thai plants. Journal of Food Composition and Analysis, 21(3), 229-240.

Rajendiran, D., Packirisamy, S., \& Gunasekaran, K. (2018). A review on role of antioxidants in diabetes. Asian Journal of Pharmaceutical and Clinical, 11(2), 48-53.

Rustanti, H. A. M. N. (2014). Pengaruh penambahan kayu manis terhadap aktivitas antioksidan dan kadar gula total minuman fungsional secang dan daun stevia sebagai aternatif minuman bagi penderita diabetes melitus tipe 2.

Sidartawan, S. (2005). Diabetes melitus : penatalaksanaan terpadu. Balai Penerbit FKUI, Jakarta.

Szkudelski, T. (2001). The mechanism of alloxan and streptozotocin action in B cells of the rat pancreas. Physiol Res, 50(6), 537-546.

Weber, K. S., Setchell, K. D., Stocco, D. M., \& Lephart, E. (2001). Dietary soy phytoestrogens decrease testosterone levels and prostate weight without altering LH, prostate 5alpha-reductase ortesticular steroidogenic acuteregulatory peptide levels in adult male sprague-dawley rats. Journal of Endocrinology, 170, 591-599.

Xu, Y.-B., Chen, G.-L., \& Guo, M.-Q. (2019). Antioxidant and anti-inflamantory activities of the crude extracts Moringa oleifera from Kenya and their correlation with flavonoid. Antioxidants, 8(296), 1-12.

Zakaria, F. R., Prangdimurti, E., Thahir, G. A. K. D. P. R., \& Suismono. (2011). Diet berbasis sorgum (Sorghum bicolor L Moench) memperbaiki proliferasi limfosit limfa dan kapasitas antioksidan hati tikus. Jurnal Pangan, 20(3), 209-222. 
